\title{
GENETIC CONTROL OF TWO MELANIC FORMS OF PANOLIS FLAMMEA (LEPIDOPTERA: NOCTUIDAE)
}

\author{
M. E. N. MAJERUS \\ Cambridge University, Department of Genetics, Downing Street, Cambridge \\ Received 19.xi.81
}

\section{SUMMARY}

\begin{abstract}
The melanic forms griseovariegata and grisea of the moth Panolis flammea are controlled by a biallelic autosomal gene, showing incomplete dominance, the typical and grisea forms being the homozygotes, and griseovariegata the heterozygote. The frequency of the grisea allele was between 0.1 and 0.2 in each of four populations sampled. Females of the three forms rest preferentially on different parts of the foodplant, Pinus sylvestris: typical moths on the trunks; griseovariegata on twigs; and grisea on needles. It is suggested that the frequency of the alleles could be affected by the number of potential resting sites of different types.
\end{abstract}

\section{INTRODUCTION}

MANY species of moth have melanic forms which have increased in frequency in recent times. With few exceptions these melanic forms have been found to be controlled by a single biallelic gene, the melanic phenotype being dominant to the typical (Bowater, 1914; Kettlewell, 1973; Lees, 1974). This paper describes work undertaken to determine the mode of inheritance of two melanic forms of the moth Panolis flammea Denis and Schiffermuller, and their relative frequencies in four locations which were monitored for varying periods from 1968 to 1981 . The forewing of Panolis flammea typically has an orange-red ground colour, sometimes more or less suffused with ochreous. The hindwing is of a pinkish brown colour. Throughout much of its range, a melanic form, ab. griseovariegata Goeze occurs. This has the forewings suffused with a bluish-or greenish-grey colour, although some red is still apparent. The hindwings are grey-brown. Lorimer (1979) notes that intermediates between the two forms exist. Another melanic form ab. grisea Tutt has also been described. In this form, the red colour is almost completely absent, being replaced by bluish or greenish-grey. The hindwings are dark grey-brown.

\section{REsults}

(i) The inheritance of griseovariegata and grisea

Between 1976 and 1981, 37 broods were reared. The stocks came from the four localities where the species was monitored; Northwood Middx; Englefield Green, Surrey; Picket Hill, near Ringwood, Hants; and Keele University, Keele, Staffs. Pinus sylvestris was used as the larval foodplant; the conditions to which broods were submitted were kept as uniform as possible. Table 1 gives details of all the broods reared. In most cases the distinction between the three forms was clear cut. However, the amount 
TABLE 1

Details of broods of $\mathrm{P}$. flammea reared

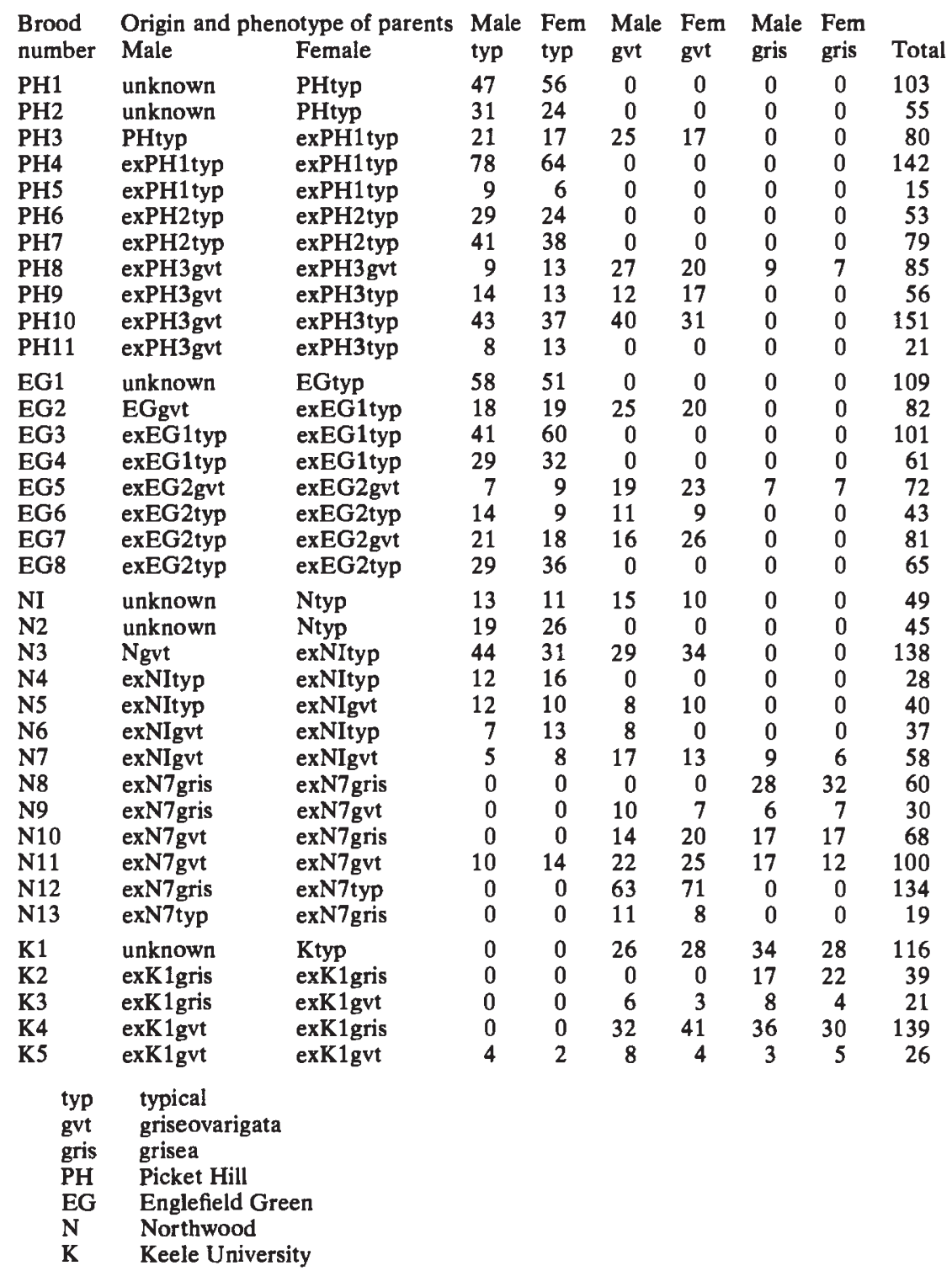

of grey scaling on the forewings in griseovariegata was variable in some broods, and a number of imagines appeared to be intermediate between griseovariegata and the typical form with regard to forewing coloration. However, in the intermediates the more greyish colour of the hindwing and the reduction in the extent of white on the cilia in griseovariegata helped in categorisation. Irrespective of the stock the data lead to the 
conclusion that the three phenotypes are controlled by a single biallelic autosomal locus showing incomplete dominance, the typical and grisea forms being homozygotes and griseovariegata the heterozygote. Typical (typ) $\times$ typ crosses were pure breeding, as were grisea (gris) $\times$ gris. griseovariegata $(\mathrm{gvt}) \times$ gvt produced segregation in a ratio approximating to 1 typ: 2 gvt: 1 gris. Gvt $\times$ typ, gvt $\times$ gris and their respective reciprocal crosses all segregated in 1:1 ratios of parental types. Typ $\times$ gris and the reciprocal cross produced solely gvt moths.

\section{(ii) The phenotypic frequencies of the forms}

The sites and periods over which the three phenotypes of P. flammea were monitored are given in table 2 . The moths were found by lighttrapping, by searching for them on tree trunks and branches of Pinus

TABLE 2

Details of samples of $\mathrm{P}$. fiammea recorded and frequency estimates for the typical and grisea alleles

\begin{tabular}{|c|c|c|c|c|c|c|c|c|c|c|}
\hline \multicolumn{2}{|c|}{ Location } & \multicolumn{2}{|c|}{ Typical } & \multicolumn{2}{|c|}{ gvt } & \multicolumn{2}{|c|}{ gris } & \multirow[b]{2}{*}{ Total } & \multicolumn{2}{|c|}{ Allelic frequency } \\
\hline and & year & Male & Fem & Male & Fem & Male & Fem & & Typical & grisea \\
\hline $\mathrm{N}$ & 1968 & 12 & 4 & 5 & 2 & 0 & 0 & 23 & 0.848 & 0.152 \\
\hline $\mathrm{N}$ & 1969 & 10 & 0 & 4 & 0 & 0 & 0 & 14 & 0.857 & 0.143 \\
\hline $\mathrm{N}$ & 1970 & 6 & 1 & 0 & 0 & 0 & 0 & 7 & 1.0 & 0.000 \\
\hline $\mathrm{N}$ & 1971 & 9 & 1 & 6 & 0 & 0 & 0 & 16 & 0.813 & 0.187 \\
\hline $\mathrm{N}$ & 1972 & 21 & 5 & 5 & 0 & 0 & 0 & 31 & 0.919 & 0.081 \\
\hline $\mathrm{N}$ & 1973 & 7 & 1 & 4 & 0 & 0 & 0 & 12 & 0.833 & 0.167 \\
\hline $\mathrm{N}$ & 1974 & 19 & 6 & 8 & 4 & 1 & 0 & 38 & 0.816 & 0.184 \\
\hline N & 1975 & 30 & 6 & 19 & 4 & 2 & 0 & 61 & 0.779 & 0.221 \\
\hline N & 1976 & 35 & 11 & 23 & 9 & 1 & 1 & 80 & 0.775 & 0.225 \\
\hline Total & & $\overline{149}$ & 35 & 74 & 19 & 4 & 1 & 282 & 0.817 & $0 \cdot 183$ \\
\hline EG & 1972 & 2 & 0 & 0 & 0 & 0 & 0 & 2 & $1 \cdot 0$ & 0.000 \\
\hline EG & 1973 & 9 & 0 & 1 & 0 & 0 & 0 & 10 & 0.950 & 0.050 \\
\hline EG & 1974 & 7 & 0 & 0 & 0 & 0 & 0 & 7 & $1 \cdot 0$ & 0.000 \\
\hline EG & 1975 & 6 & 1 & 0 & 0 & 0 & 0 & 7 & $1 \cdot 0$ & 0.000 \\
\hline EG & 1976 & 14 & 1 & 1 & 0 & 0 & 0 & 16 & 0.969 & 0.031 \\
\hline EG & 1977 & 6 & 0 & 0 & 1 & 0 & 0 & 7 & 0.929 & 0.071 \\
\hline EG & 1978 & 9 & 1 & 0 & 0 & 0 & 0 & 10 & $1 \cdot 0$ & 0.000 \\
\hline EG & 1979 & 2 & 0 & 0 & 0 & 0 & 0 & 2 & $1 \cdot 0$ & 0.000 \\
\hline Total & & $\overline{55}$ & 3 & 2 & 1 & 0 & 0 & $\overline{61}$ & 0.975 & 0.025 \\
\hline PH & 1975 & 11 & 2 & 0 & 1 & 0 & 0 & 14 & 0.964 & 0.036 \\
\hline PH & 1976 & 18 & 2 & 3 & 0 & 1 & 0 & 24 & 0.896 & 0.104 \\
\hline PH & 1977 & 14 & 3 & 2 & 1 & 1 & 0 & 21 & 0.881 & 0.119 \\
\hline $\mathrm{PH}$ & 1978 & 4 & 0 & 0 & 1 & 0 & 0 & 5 & 0.900 & $0 \cdot 100$ \\
\hline PH & 1979 & 15 & 2 & 4 & 1 & 0 & 0 & 22 & 0.886 & 0.114 \\
\hline $\mathrm{PH}$ & 1980 & 3 & 1 & 1 & 0 & 0 & 0 & 5 & 0.900 & 0.100 \\
\hline Total & & $\overline{65}$ & $\overline{10}$ & $\overline{10}$ & 4 & 2 & 0 & 91 & 0.901 & 0.099 \\
\hline K & 1979 & 7 & 2 & 2 & 1 & 1 & 0 & 13 & 0.808 & 0.192 \\
\hline $\mathbf{K}$ & 1980 & 9 & 2 & 2 & 0 & 0 & 1 & 14 & 0.857 & $0 \cdot 143$ \\
\hline Total & & $\overline{16}$ & 4 & 4 & $\frac{1}{1}$ & $\overline{1}$ & 1 & $\overline{27}$ & 0.833 & 0.167 \\
\hline
\end{tabular}

N Northwood

EG Englefield Green

PH Picket Hill

K Keele University (approx grid ref. TQ082906) (SU996698)

(SU185065)

(SJ823440) 
sylvestris, by beating low foliate branches of Scots pine, and by searching sallow blossom at dusk. Once recorded, moths were marked to prevent rerecording. The data collected are presented in table 2, together with allelic frequency estimates.

Both of the melanic forms were rarer than the typical form in all four of the populations surveyed. The highest frequencies of the grisea allele were in the samples from Northwood and Keele. Although both these sample areas are affected by industrial pollutants, the significantly higher frequency of the melanic forms at Picket Hill than at Englefield Green might argue against the melanism being principally due to industrial pollution, because the Picket Hill site is the least affected by pollutants. These data thus give some slight support to the supposition that the melanics are non-industrial (Kettlewell, 1973), and that they should be categorised as rural melanics.

\section{(iii) The resting sites of the three forms}

During the day, imagines of $P$. flammea usually rest on the trunks, branches or amongst the foliage of Scots pine. When sampling moths for estimating allelic frequencies 108 were found on pines. The resting sites of these moths were recorded according to three categories:

(1) On the pine trunks.

(2) On non-foliate parts of main branches.

(3) On foliate twigs or amongst needles.

Only one moth was of the grisea form. The positions of moths of the typical and griseovariegata forms are given in table 3, together with the overall heterogeneity chi-squared for this data. No significant difference was observed in the position taken up by males of these forms $\left(\chi_{2}^{2}=0.576\right.$; $p>0.7)$. However the majority of typical females rested on trunks while most griseovariegata females rested on foliate twigs, this difference being highly significant $\left(\chi_{2}^{2}=13.939 ; p<0.001\right)$.

TABLE 3

Positions of wild $\mathrm{P}$. flammea imagines taken at rest on $\mathrm{P}$. sylvestris

(1) Trunks

(2) Branches

(3) Foliate twigs

$\begin{array}{cc}\text { Male typ } & \text { Fem typ } \\ 16 & 21 \\ 11 & 8 \\ 12 & 6 \\ 39 & 35\end{array}$

Male gvt
7
3
6
16

Fem gvt
2
4
11
17

Total

Overall heterogeneity $\chi_{6}^{2}=14 \cdot 807, p=0 \cdot 022$.

As only one wild moth of the grisea form was seen at rest on pine, an experiment was set up to obtain data on the resting sites of this form using bred, marked moths. Equal numbers of males and females were used. 150 moths of each phenotype were released in the vicinity of a small stand of seven mature Scots pines on Picket Hill Heath in 1981. The moths were released at 7.00 a.m. The pines were examined between 2.00 and 6.00 p.m. the same day and all moths found were collected, the positions on the tree being noted. The resting sites were categorised as previously except that 
TABLE 4

The positions of released $\mathrm{P}$. flammea recollected from $\mathrm{P}$. sylvestris

\begin{tabular}{lcrrrrrr} 
Site type & \multicolumn{3}{c}{ Males } & gvt & gris & Typ & Females \\
(1) Trunks & 15 & 11 & 9 & 16 & 4 & gris & Total \\
(2) Branches & 7 & 7 & 5 & 6 & 7 & 5 & 58 \\
(3a) Twigs & 9 & 7 & 10 & 4 & 9 & 5 & 44 \\
(3b) Needles & 1 & 2 & 4 & 2 & 5 & 12 & 26 \\
& 32 & 27 & 28 & 28 & 25 & 25 & 165
\end{tabular}

Overall heterogeneity $\chi_{15}^{2}=38.978, p=0.00065$.

class (3) was split into two divisions; 3(a) twigs; and 3(b) needles. The results are given in table 4 . Only seven males rested amongst needles, and so, for males, classes 3(a) and 3(b) were grouped together. There was no significant difference in the resting sites of the male phenotypes $\left(\chi_{4}^{2}=2 \cdot 820\right.$; $p>0.5)$, although a greater proportion of grisea males than either of the other forms was found on foliate twigs.

The data for females show a significant difference in the behaviour of the three forms $\left(\chi_{6}^{2}=23.794 ; p<0.001\right)$. Again typicals rest most frequently on trunks and griseovariegata on twigs, the difference being significant $\left(\chi_{2}^{2}=10.340 ; p<0.01\right)$. The proportion of female moths, of these forms, resting on twigs compared with needles is similar in both cases; about two-thirds resting on twigs. This is in contrast to grisea females of which a significantly greater number rested on needles than on twigs when compared with the other forms $\left(\chi_{1}^{2}=4.659 ; p<0.05\right)$.

It should also be noted that although the analysis of data in both tables 3 and 4 shows that the females exhibit a significant tendency to select sites, while males do not exhibit such a tendency, there is no significant difference in the behaviour of males and females (for table 3 data, $\chi_{6}^{2}=7 \cdot 36, p=0.061$; for table 4 data $\chi_{8}^{2}=6 \cdot 61, p=0 \cdot 58$ ). This raises doubt as to whether the differential behaviour is confined to females or not.

The results of the resting site tests mean that the allelic frequency estimates must be reappraised as sampling would not be random if samples were sought more on pine trunks than on foliate twigs or vice-versa. In fact the frequency estimates noted in table 2, would seem to be reliable. Firstly the majority of imagines sampled were males. Secondly, some females were taken in a MV moth trap, and there is no indication that the three forms react to the MV light in different ways. Thirdly, even amongst those females taken on pine, the frequency of the forms was not significantly different from those in the rest of the samples for each area.

\section{Discussion}

The presence of incomplete dominance makes this an unusual example of melanism. Ford (1937) suggested that industrial melanism in the Lepidoptera will usually involve completely dominant melanic genes. Indeed there are relatively few known examples of incomplete dominance in polymorphisms among the Lepidoptera. If as is suggested by the extremely cryptic coloration of its typical form, $P$. flammea is subject to intensive visual predation, then dominance modification would be expected 
to evolve as long as an allelomorph is not too rare (Fisher, 1928; Haldane, 1956; Clarke and Sheppard, 1960), or the origin of the polymorphism is very recent (Ford, 1971), which is unlikely as Goeze described griseovariegata in 1781, and both melanic forms are well represented in 19th century collections. The behavioural difference between females of the three forms undoubtedly causes the moths to rest in positions where their coloration most closely matches their background: the reddish typical form -on the reddish coloured bark of Scots pine, the intermediate griseovariegata form on the twigs of the tree which are less red, and the bluish or greenish-grey form on the needles which are described as being of a dull blue-green colour. The differential behaviour of the three forms may be controlled by the same gene as the wing coloration or, as seems more likely, by a closely linked one. Whichever the case the gene's relation to behaviour may be sex-limited. However, it is difficult to see why the difference in behaviour should be confined to females, or, if it is, why the colour variation is not also sex-limited, though the survival of females may be more important to the species than the survival of males, as the males are polygamous (pers. obs.).

The correlation between phenotype colour and the colour of the preferred resting sites is consistent with the view that selection by predators (such as birds) which use colour vision to find prey, has been involved in the evolution of the polymorphism. Apostatic selection by birds which form searching images can maintain a polymorphism by conferring a selective advantage on rare forms (Clarke, 1962, 1969; Allen and Clarke, 1968; Allen, 1972a, $b, 1974)$. It may be an advantage to an organism which is at risk from predators which employ search images to have as many forms as possible within the constraints of its biology and ecology. Therefore, an advantage could by gained by the retention of a distinct heterozygote, as in the case of the olive heterozygote in larvae of Phlogophora meticulosa (Majerus, 1978).

Alternatively or concurrently, the retention of three distinct forms which employ different resting sites could be beneficial if the number of potential resting sites is limited. If, for example, the number of trunk and branch sites was limited, so that other sites such as twigs or needles had to be used, forms which matched this type of site would gain an advantage until their frequency reached a level which would be, at least in part, dependent on the number of suitable resting sites available. It is worth noting that the range of $\boldsymbol{P}$. flammea has greatly increased in recent times by large-scale planting of pine, and populations can survive among low concentrations of pine planted in parks and gardens (Lorimer, 1979).

If the number of potential resting sites does affect the maintenance of the polymorphism, the growth habit of Pinus sylvestris, and other types of pine used by $P$. flammea e.g., Pinus pinaster, may affect the frequency of the forms. Typically, mature solitary trees are dome-shaped with little dominance of the leader shoot over side shoots which are almost all foliate. However, in the close stands of forestry plantations the leader shoot is markedly dominant, producing rapid growth which leads to tall spire-like trees, with the foliate branches confined to the top third of the trees (Watson, 1981). Such differences in the tree form obviously provide different ratios of foliate compared with non-foliate resting sites. That the frequency of the grisea allele was greater in the Northwood and Keele 
populations where most of the pines were mature, solitary trees, than in the Picket Hill or Englefield Green populations, where sampling sites were in or on the edge of pine plantations, indicates that there may indeed be a correlation between the frequency of grisea and the density and form of pines in an area.

\section{REFERENCES}

ALLEN J. A. 1972a. Evidence for stabilising and apostatic selection by wild blackbirds. Nature, $237,348-349$.

Allen J. A. 1972b. Apostatic Selection: The Responses of Wild Passerines to Artificial Polymorphic Prey. Ph.D. Thesis, University of Edinburgh.

ALLEN, J. A. 1974. Further evidence for apostatic selection by wild passerine birds: Training experiments. Heredity, 33, 361-372.

ALLEN, J. A., AND CLARKE, B. 1968. Evidence for apostatic selection by wild passerines. Nature, 220, 501-502.

BOWATER, W. 1914. Heredity of melanism in Lepidoptera. J Genet., 3, 299-315.

CLARKE, B. 1962. Natural selection in mixed populations of two polymorphic snails. Heredity, $17,319-345$.

CLARKE, B. 1969. The evidence for apostatic selection. Heredity, 24, 347-352.

CLARKE, C. A., AND SHEPPARD, P. M. 1960. The evolution of dominance under disruptive selection. Heredity, 14, 73-87.

FISHER, R. A. 1928. The possible modification of the response of the wild type to recurrent mutations. Am. Nat., 62, 115-126.

FORD, E. B. 1937. Problems of heredity in the Lepidoptera. Biol Rev., 12, 461-503.

FORD, E. B. 1971. Ecological Genetics, 3rd edition. Chapman and Hall, London.

HALDANE, J. B. S. 1956. The theory of selection for melanism in the Lepidoptera. Proc. $\boldsymbol{R}$. Soc. B., 145, 303-308.

KetTLEWELL, H. B. D. 1973. The Evolution of Melanism. Clarendon Press, Oxford.

LEES, D. R. 1974. The genetic control of the melanic forms of the moth Phigalia pilosaria (Pedaria) Heredity, 33, 145-150.

LORIMER, R. I. 1979. In Heath, J., and Emmet, A. M. (eds.) The Moths and Butterflies of Great Britain Ireland, vol. 9. Curwen, London.

MAJeRUS, M. E. N. 1978. The Control of Larval Colour in Phlogophora meticulosa (Lepidoptera: Noctuidae). Ph.D. Thesis, Royal Holloway College, University of London.

Watson, E. V. 1981. In Hora, B. (ed.) The Oxford Encyclopaedia of Trees of the World. Oxford University Press, Oxford. 